Article

\title{
Simultaneous Production of Transformer Insulating Oil and Value-Added Glycerol Carbonates from Soybean Oil by Lipase-Catalyzed Transesterification in Dimethyl Carbonate
}

\author{
Keon Hee Kim and Eun Yeol Lee * \\ Department of Chemical Engineering, Kyung Hee University, Gyeonggi-do 17104, Korea; geoni@khu.ac.kr \\ * Correspondence: eunylee@khu.ac.kr; Tel.: +82-31-201-3839
}

Received: 30 November 2017; Accepted: 27 December 2017; Published: 30 December 2017

\begin{abstract}
Fatty acid methyl esters (FAMEs), as a transformer insulating oil, and value-added glycerol derivatives were simultaneously synthesized from soybean oil by transesterification using Lipozyme 435 in dimethyl carbonate (DMC). The conversion of transformer insulating oil and glycerol derivatives reached $92 \%$ and $72 \%$, respectively, under optimum conditions (DMC-to-oil molar ratio of $4.5: 1$ with $0.5 \mathrm{v} / \mathrm{v} \%$ water and $15 \mathrm{wt}$. \% Lipozyme 435 at $70{ }^{\circ} \mathrm{C}$ ) in one-pot batch reactions. The purified transformer insulating oil possessed a dielectric breakdown voltage of $82.0 \mathrm{kV}$, which is sufficiently high for transformer insulation oil applications. Other properties such as density, dielectric breakdown voltage, and viscosity were comparable or superior to those of mineral oil, confirming that achieved material could be used as an alternative transformer insulating oil. Additionally, the glycerol was simultaneously converted into glycerol derivatives, which can be utilized as ingredients for cosmetics or monomers for bio-based plastics. This study clearly demonstrates that transformer insulating oil and value-added glycerol derivatives were simultaneously produced based on the zero-waste utilization of soybean oil.
\end{abstract}

Keywords: soybean oil; transformer insulating oil; glycerol derivatives; lipase; transesterification

\section{Introduction}

A transformer is a static electronic equipment that transforms voltages and transfers energy via inductive coupling. Inner transformers are filled with an insulating oil for heat transfer and insulation [1]. Petroleum-based insulating fluid such as mineral oil is the most commonly used transformer insulating fluid transformers [2]. However, it has several drawbacks such as its limited relevant resources, sulfidation corrosion, poor biodegradability (less than $30 \%$ ), and environmental issues when it is spilled in soil or in water [3,4].

In recent years, ecofriendly transformer insulating oils based on renewable and biodegradable vegetable oils have been considered as alternative insulating fluids. Transformer insulating bio-oils provide pollution-free advantages because they have high biodegradability and low toxicity $[4,5]$. The dielectric breakdown voltage is the most important parameter of an insulating oil. Generally, this is sensitive to impurities (e.g., gas or air bubbles and excessive moisture, etc.) in the insulating fluid [4]. However, using natural ester as a transformer insulating oil can maintain high dielectric breakdown voltages at relatively high moisture levels because it creates hydrogen bonds with water molecules [6-8].

Vegetable oil-based transformer insulating oils can be produced by partial hydrogenation or transesterification. Conventional transesterification reactions refer to the production of fatty acid methyl esters (FAMEs) between oil and methanol, with the generation of glycerol, in the presence 
of base catalysts [9]. Glycerol is a byproduct of biodiesel and transformer insulating oil production, and accounts for approximately $10 \mathrm{wt}$. \% of the total production [10]. The overproduction of glycerol has led to its significant price decline and a glut of this commodity in the world's market [11,12]. Moreover, the lack of purity in glycerol obtained by transesterification reactions hinders its utilization in the pharmaceutical and cosmetic industries [11]. In order to solve this technical issue, we have employed dimethyl carbonate (DMC) instead of alcohol for glycerol-free transesterification [13-16]. DMC-based transesterification can simultaneously produce FAMEs (as a transformer insulating oil) and glycerol derivatives, including glycerol carbonate and glycerol dicarbonate. Glycerol derivatives are high-value products. Glycerol carbonate has many applications in surfactants, cosmetics, pharmaceuticals, coating materials, and monomers for polymeric materials due to several properties including its low toxicity, low flammability, and low vapor pressure [17,18]. However, the production of transformer insulating oil under glycerol-free transesterification using DMC as an acyl acceptor and a substrate for glycerol derivatives has never been investigated.

In this study, transformer insulating oil of FAMEs and value-added glycerol derivatives were simultaneously produced from soybean oil and DMC through transesterification using lipase. Herein, DMC was employed as the reaction solvent, acyl acceptor, and substrate for the synthesis of glycerol derivatives. The parameters (DMC-to-oil ratio, water addition, enzyme loading, and reaction temperature and time) to optimize the conversion of transformer insulating oil were investigated. The resulting transformer insulating oil was investigated to evaluate its properties, including the dielectric breakdown voltage, as an insulating fluid. The price of transformer insulating oil is higher than biodiesel and glycerol derivatives can be used in versatile commercial applications. Therefore, the simultaneous production of high-value products (transformer insulation oil and glycerol derivatives) might enhance the economic feasibility of industrial scale implementation of this process.

\section{Results and Discussion}

\subsection{Basic Reaction Pathway of DMC-Based Transesterificaton}

DMC is used an acyl acceptor to prevent the co-production of glycerol, and it is a versatile solvent due to its neutral, odorless, non-corrosive, and non-toxic properties [19]. During DMC-based transesterification, glycerol derivatives were produced as byproducts; these have a higher market value than glycerol. Therefore, DMC-based transesterification is a prudent way to make glycerol-free fuel production more viable [20].

The components produced in transformer insulating oil (FAMEs) synthesis were confirmed by gas chromatography/mass spectrometry (GC/MS) Temperature programming was modified based on a reference to efficiently separate the main products, byproducts, and intermediate products [21]. As shown in Figure 1a, the main products (i.e., FAMEs) were found in the range of 6-14 min by comparing with standard substances. Glycerol carbonate and glycerol dicarbonate (i.e., the byproducts) were confirmed at $1.4 \mathrm{~min}$ and $2.4 \mathrm{~min}$, respectively. The intermediate products, with retention times of $16.5 \mathrm{~min}, 18.4 \mathrm{~min}$, and $18.6 \mathrm{~min}$, were characterized as cyclic fatty acid glycerol carbonate esters (FAGCs) with fatty acid acyl residues of 1-palmitoyl, 1-linoleoyl, and 1-stearoyl, respectively. The major fragments taken from mass spectra of FAGCs were compared with reference data [21,22]. Figure 1b proposes a general transesterification pathway of soybean oil and DMC. Transesterification with DMC can go through three stepwise reactions. Initially, one molecule of triglycerides (TG) reacts with three molecules of DMC to produce FAMEs and FAGCs. Then, one molecule of FAGCs further reacts to produce FAMEs and glycerol dicarbonate. Finally, glycerol carbonate is generated from glycerol dicarbonate through hydrolysis. The final reaction is an irreversible reaction because of the carbon dioxide formation. 


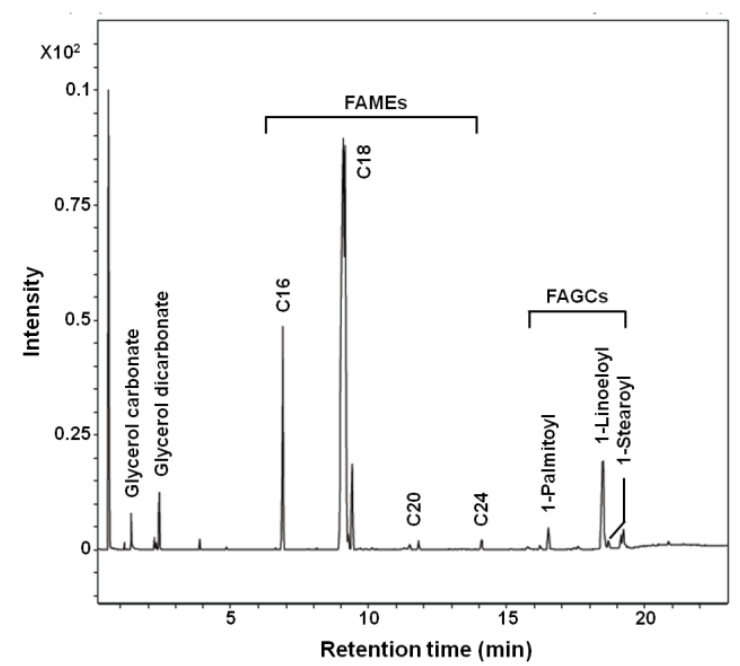

(a)

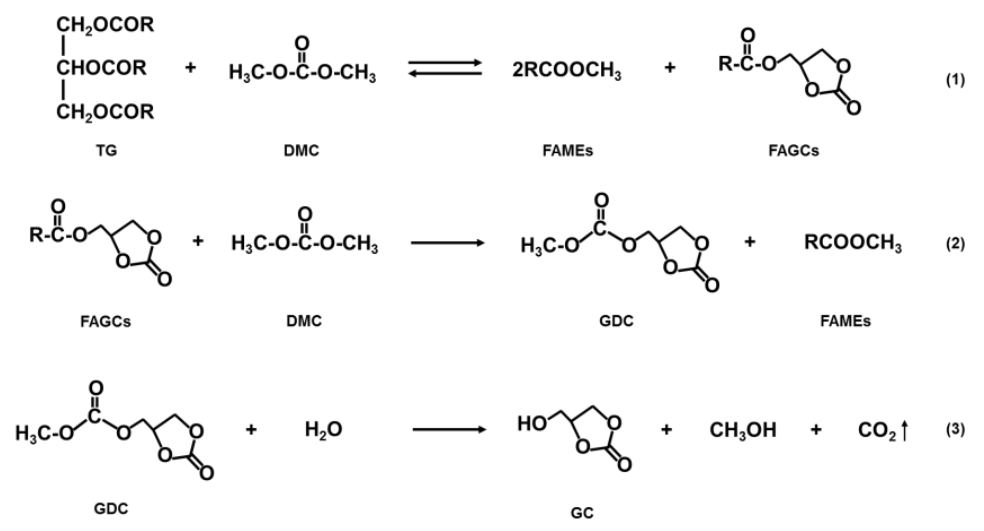

(b)

Figure 1. (a) Chromatogram for the FAMEs (transformer insulating oil) synthesized from soybean oil and DMC in the presence of Lipozyme 435. Reaction conditions: $0.874 \mathrm{~g}$ of soybean oil, 4.5:1 molar ratio of DMC to oil, $0.5 \mathrm{v} / \mathrm{v} \%$ of water, $15 \mathrm{wt}$. \% of Lipozyme 435 at $50{ }^{\circ} \mathrm{C}$ for $3 \mathrm{~h}$. (b) Reaction pathway for transesterification with soybean oil and DMC. Triglyceride (TG); dimethyl carbonate (DMC); fatty acid methyl esters (FAMEs); fatty acid glycerol carbonate esters (FAGCs); glycerol dicarbonate (GDC); glycerol carbonate (GC).

\subsection{Biosynthesis of Transformer Insulating Oil Using Dimethyl Carbonate as an Acyl Acceptor}

\subsubsection{Effect of DMC-to-Soybean Oil Molar Ratio}

The DMC-to-oil molar ratio is the most important parameter affecting the transformer insulating oil conversion. In order to lead the synthesis of transformer insulating oil, the amount of DMC is required to be more than the stoichiometric ratio because the reaction between oil and DMC is reversible [21,23]. Figure 2 depicts the change of transformer insulating oil conversion with various molar ratios of DMC to soybean oil. When increasing the DMC-to-soybean oil molar ratio from $1: 1$ to $4.5: 1$, the relative transformer insulating oil conversion increased, and this conversion became almost constant when the DMC molar ratio increased above 4.5. Based on the transformer insulating oil conversion, the appropriate DMC-to-soybean oil molar ratio was selected to be $4.5: 1$ for further experiments. 


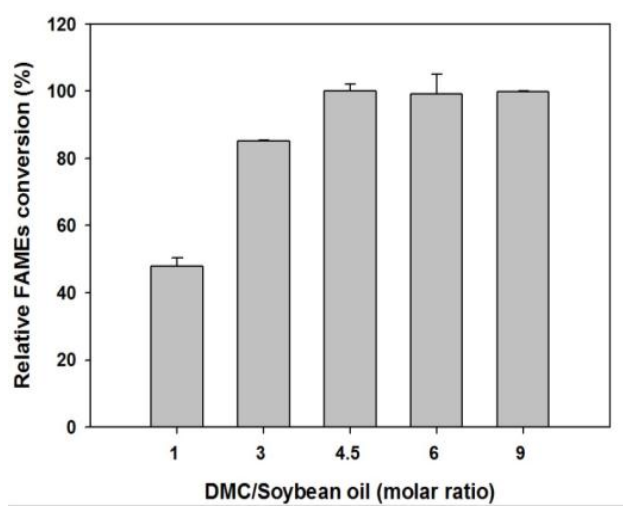

Figure 2. Effect of the DMC-to-soybean oil molar ratio on the reaction of transesterification. Reaction conditions: $0.874 \mathrm{~g}$ of soybean oil, different ratios of DMC, $0.2 \mathrm{v} / \mathrm{v} \%$ of water, $5 \mathrm{wt}$. \% of Lipozyme 435 at $50{ }^{\circ} \mathrm{C}$ for $3 \mathrm{~h}$.

\subsubsection{Effect of Water Addition}

When lipase is used as a biocatalyst it requires a certain amount of water to retain its activity and stability because water provides an aqueous-organic interface to preserve the three-dimensional structure of the enzyme during non-aqueous reactions [9]. However, lipase usually catalyzes hydrolysis under aqueous media, thus excessive water causes a hydrolysis reaction and reduces conversion rate [24]. Various water contents from 0 to $1 \%(\mathrm{v} / \mathrm{v})$ were investigated to determine the appropriate amount of water for transesterification. As the amount of water was raised from $0 \%$ to $0.5 \%(\mathrm{v} / \mathrm{v})$, the relative transformer insulating oil conversion was gradually increased (Figure 3). Further increases in the water content above $0.5 \%(\mathrm{v} / \mathrm{v})$ caused a decrease in the relative transformer insulating oil conversion. Therefore, the optimum water content was set to $0.5 \%(\mathrm{v} / \mathrm{v})$ for further experiments.

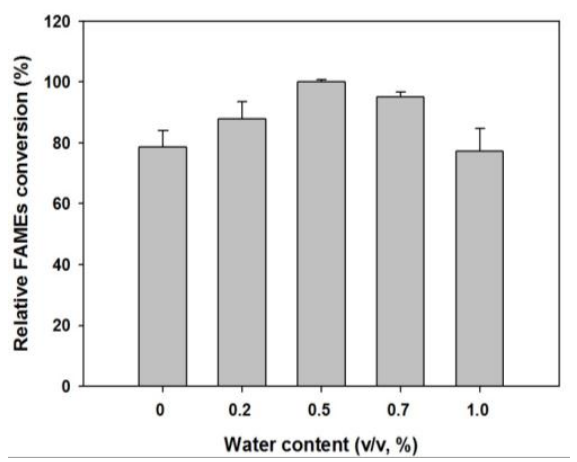

Figure 3. Effect of water content on the transesterification reaction. Reaction conditions: $0.874 \mathrm{~g}$ of soybean oil, 4.5:1 molar ratio of DMC to oil, $5 \mathrm{wt}$. \% of Lipozyme 435 with different water additions at $50{ }^{\circ} \mathrm{C}$ for $3 \mathrm{~h}$.

\subsubsection{Effect of Enzyme-to-Soybean Oil Ratio}

The use of enzymes as biocatalysts for biofuel production is expensive compared to chemical catalysts [14]. Thus, it is important to find the appropriate amount of enzyme that can produce a high conversion of transformer insulating oil. Here, the proper amount of Lipozyme 435 for transformer insulating oil conversion was investigated between $2 \%$ and $20 \%(\mathrm{w} / \mathrm{w})$ based on the soybean oil mass. During the early stage of transformer insulating oil biosynthesis, the relative transformer insulating oil conversion rapidly increased as the enzyme amount increased from 2 to $20 \%$ ( $3 \mathrm{~h}$; Figure 4 ). This means that a large amount of enzyme leads to a higher reaction rate in the initial stage. Thus, the reaction time was increased up to the saturation stage $(12 \mathrm{~h})$ for sufficient reaction by lipase. The relative transformer insulating oil conversion gradually increased while the amount of enzyme increased up to 
$15 \%$, but further increases in the enzyme amount did not significantly affect the relative transformer insulating oil conversion. From these results, the appropriate amount of enzyme for transformer insulating oil biosynthesis was determined to be $15 \%(w / w)$.

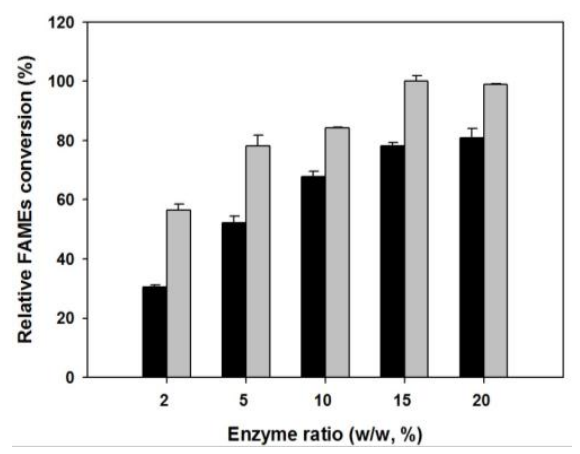

Figure 4. Effect of the enzyme-to-soybean oil weight ratio on the transesterification reaction. Reaction conditions: $0.874 \mathrm{~g}$ of soybean oil, 4.5:1 molar ratio of DMC to oil, $0.5 \mathrm{v} / \mathrm{v} \%$ of water, with different enzyme-to-oil ratios at $50{ }^{\circ} \mathrm{C}$ for $3 \mathrm{~h}$ and $12 \mathrm{~h}$. Symbols: $3 \mathrm{~h}$ (black bar), $12 \mathrm{~h}$ (gray bar).

\subsubsection{Effect of Reaction Temperature and Time}

A higher temperature in transesterification has a positive effect on the reaction rate due to the exothermic characteristics [9]. In addition, the oil viscosity and the reaction time can be reduced by a high reaction temperature [25]. However, denaturation of the enzyme can occur if the temperature is increased too much, which would lead to a decrease in its activity. In general, the optimum activity of lipase is achieved between 20 and $70{ }^{\circ} \mathrm{C}$ [14]. Lipase-catalyzed reactions were carried out between 30 and $70{ }^{\circ} \mathrm{C}$ to determine the optimal reaction temperature for transformer insulating oil conversion (Figure 5). As the reaction temperature increased up to $70^{\circ} \mathrm{C}$, the initial synthesis rate of transformer insulating oil gradually increased. The transformer insulating oil synthesis quickly reached $92 \%(\mathrm{w} / \mathrm{w})$, based on the soybean oil, after a reaction time of $6 \mathrm{~h}$ at $70^{\circ} \mathrm{C}$; the productivity of transformer insulating oil from soybean oil was $351.8 \mathrm{~g} / \mathrm{L} / \mathrm{h}$. Although the initial rate at $50{ }^{\circ} \mathrm{C}$ was low, after $24 \mathrm{~h}$ the final transformer insulating oil conversion was similar to that obtained at a reaction temperature of $70^{\circ} \mathrm{C}$. The optimum reaction temperature based on the productivity was thus determined to be $70^{\circ} \mathrm{C}$.

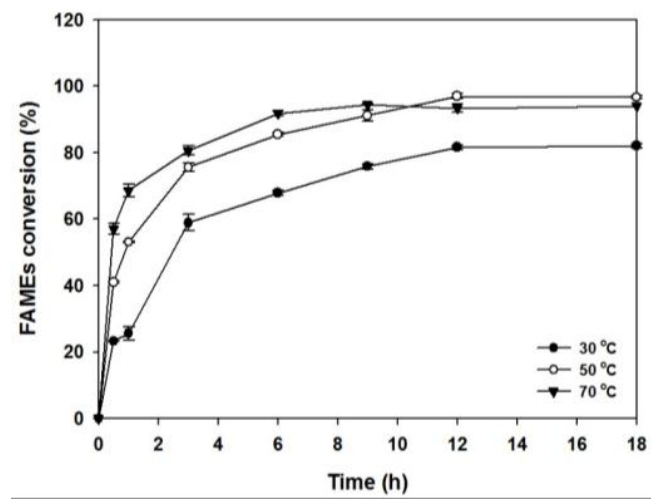

Figure 5. Effect of reaction temperature and time on the transesterification reaction. Reaction conditions: $0.874 \mathrm{~g}$ of soybean oil, 4.5:1 molar ratio of DMC to oil, $0.5 \mathrm{v} / \mathrm{v} \%$ of water, $15 \mathrm{wt}$. \% of Lipozyme 435 at the given temperatures and times.

\subsection{Characterization of Glycerol Carbonate and Glycerol Dicarbonate}

In order to confirm the structure and amount of glycerol carbonate and glycerol dicarbonate, the glycerol derivatives generated from soybean oil and DMC were analyzed by gas chromatography (GC) 
and GC/MS (Figure 6). Glycerol carbonate was compared with a standard substance, and glycerol dicarbonate was in good agreement with the reference data obtained from the main fragment $(\mathrm{m} / \mathrm{z} 59$ and $\mathrm{m} / \mathrm{z}$ 100) [21]. The rate of glycerol dicarbonate synthesis was faster than that of glycerol carbonate synthesis in the early stage (Figure 7). This is consistent with the reaction pathway shown in Figure 1b, showing that glycerol dicarbonate is synthesized first rather than glycerol carbonate. According to the final step of reaction pathway in Figure 1b, the amount of glycerol dicarbonate would decrease due to its conversion to glycerol carbonate via hydrolysis. Interestingly, both glycerol dicarbonate and glycerol carbonate were saturated with increasing the reaction time. It important to note that the amount of water added for maintaining lipase activity was very small, around $0.11 \mathrm{mmol}(0.5 \mathrm{v} / \mathrm{v} \%$ water); thus, the amount of water was not enough to convert glycerol dicarbonate to glycerol carbonate in Figure 7 . Based on these results, we suggest that both reaction pathways, as shown in Figures $1 \mathrm{~b}$ and 8 , might simultaneously occur in the reaction.

At $60 \mathrm{~h}$, glycerol carbonate and glycerol dicarbonate were produced at a molar ratio of 1.63:1. Based on the theoretical yield, the conversion of glycerol derivatives was determined to be $72 \%$. Glycerol dicarbonate can be converted into glycerol carbonate via hydrolysis. Therefore, the conversion of glycerol derivatives was calculated by assuming that the generated glycerol dicarbonate was converted into glycerol carbonate. This glycerol-free transformer insulating oil synthesis, which uses DMC-based transesterification, has a distinct advantage in that the glycerol removal step can be omitted [26]. Additionally, the purified glycerol derivatives can be used as ingredients for pharmaceuticals and cosmetics as well as for the monomers of bio-based plastics [17].

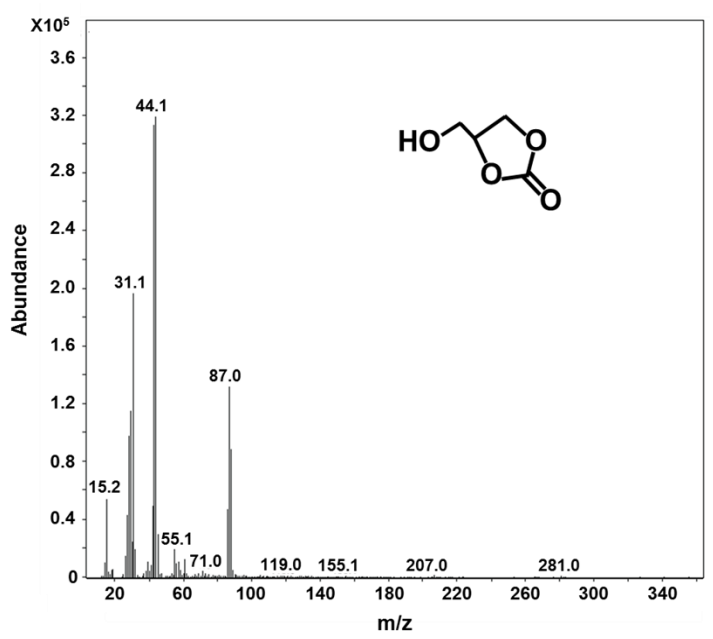

(a)

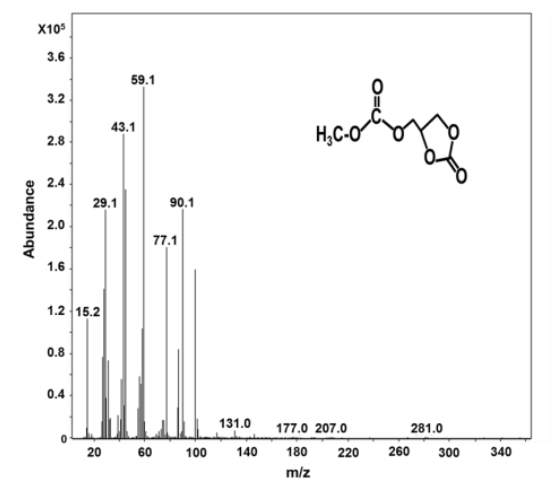

(b)

Figure 6. Mass spectra of (a) glycerol carbonate and (b) glycerol dicarbonate. 


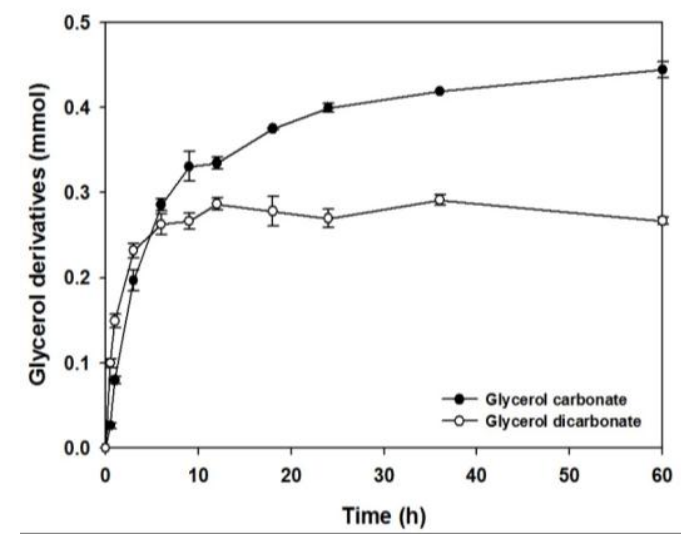

Figure 7. Batch reaction for the production of glycerol carbonate and glycerol dicarbonate from soybean oil and DMC under the optimized conditions. Reaction conditions: $0.874 \mathrm{~g}$ of soybean oil, 4.5:1 molar ratio of DMC to oil, $0.5 \mathrm{v} / \mathrm{v} \%$ of water, $15 \mathrm{wt}$. \% of Lipozyme 435 at $70{ }^{\circ} \mathrm{C}$.

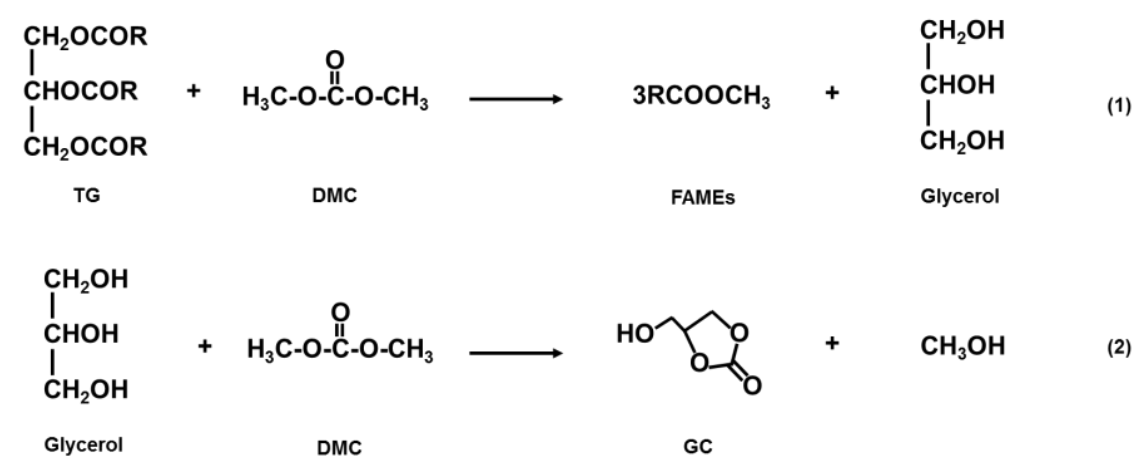

Figure 8. Possible reaction pathway for transesterification with soybean oil and DMC. Triglyceride (TG); dimethyl carbonate (DMC); fatty acid methyl esters (FAMEs); glycerol carbonate (GC).

\subsection{Transformer Insulating Oil Properties}

The properties of the FAMEs prepared as a transformer insulating oil are shown in Table 1. The transformer insulating oil had a density of 0.919 . The kinematic viscosity values of the transformer insulating oil were $6.66 \mathrm{~mm}^{2} / \mathrm{s}$ and $2.29 \mathrm{~mm}^{2} / \mathrm{s}$ at $40^{\circ} \mathrm{C}$ and $100{ }^{\circ} \mathrm{C}$, respectively, which are similar to those of mineral oil. Oil with low viscosity is worth using as transformer insulating oil due to the enhanced cooling efficiency of transformers [2]. The transformer insulating oil exhibited a dielectric breakdown voltage of $82.0 \mathrm{kV}$, indicating that the transformer insulating oil has a higher dielectric breakdown voltage than mineral oil and natural ester. Therefore, transformer insulating oil of FAMEs can be considered as an alternative dielectric fluid because of their excellent insulation properties and low kinematic viscosity. The flash point of transformer insulating oil was $124{ }^{\circ} \mathrm{C}$, which is lower than that of natural ester. High flash point is required for better safety during transformer operation. One weak point of the transformer insulating oil is that the pour point occurred at $0{ }^{\circ} \mathrm{C}$. This can provoke easy crystallization at low temperatures. Thus, attempts to improve the flash point and the liquidity at low temperatures need to be conducted in further experiments.

The transformer insulating oil can be expected to be economically feasible due to the higher supply cost for transformer insulating oil compared to biodiesel. The simultaneous production of transformer insulating oil and value-added glycerol derivatives provides a zero-waste utilization of soybean oil. In addition, the net carbon dioxide emission in methanol-based biodiesel production from soybean is known to be $-72.73 \mathrm{~g} / \mathrm{MJ}$ [27]. When considering that DMC can potentially be produced from carbon dioxide through $\mathrm{CO}_{2}$ sequestration and conversion, DMC-based transesterification can be considered a more environment-friendly process than conventional transesterification using methanol. 
Table 1. Properties of the soybean oil-based transformer insulating oil.

\begin{tabular}{|c|c|c|c|c|c|}
\hline \multicolumn{2}{|c|}{ Properties } & Unit & Mineral Oil & Natural Ester ${ }^{a}$ & In This Study \\
\hline \multicolumn{2}{|c|}{ Density } & $\mathrm{g} / \mathrm{cm}^{3}$ & $<0.91$ & 0.92 & 0.92 \\
\hline \multirow{2}{*}{ Viscosity } & $40^{\circ} \mathrm{C}$ & \multirow{2}{*}{$\mathrm{mm}^{2} / \mathrm{s}$} & $<13.0$ & 33.0 & 6.66 \\
\hline & $100^{\circ} \mathrm{C}$ & & $<4.0$ & - & 2.29 \\
\hline \multicolumn{2}{|c|}{ Pour point } & ${ }^{\circ} \mathrm{C}$ & $<-27.5$ & - & 0 \\
\hline \multicolumn{2}{|c|}{ Flash point } & ${ }^{\circ} \mathrm{C}$ & 140.0 & 316.0 & 124.0 \\
\hline \multicolumn{2}{|c|}{ Dielectric breakdown voltage } & $\mathrm{kV}$ & $>40.0$ & 56.0 & 82.0 \\
\hline \multicolumn{2}{|c|}{ Moisture } & $(\mathrm{m} / \mathrm{m}) \%$ & $<0.003$ & - & 0.017 \\
\hline \multirow{2}{*}{$\begin{array}{l}\text { Oxidation } \\
\text { stability }\end{array}$} & Sludge & $\%$ & - & - & $<0.01$ \\
\hline & Acid value & $\mathrm{mg} \mathrm{KOH} / \mathrm{g}$ & $<0.40$ & - & 0.30 \\
\hline
\end{tabular}

\section{Materials and Methods}

\subsection{Materials}

Lipozyme 435 was obtained from Double-U (Seoul, Korea). Commercial refined soybean oil was supplied by the CJ Company (Seoul, Korea). Fatty acid methyl ester standards (C16:0, C18:0, C18:1, C18:2, C18:3) were supplied by Sigma (St. Louis, MO, USA). DMC was purchased from Acros Organics (Morris Plains, NJ, USA). In this study, all chemicals used were of analytical reagent grade.

\subsection{Simultaneous Biosynthesis of Transformer Insulating Oil and Glycerol Derivatives}

\subsubsection{Optimization of Transesterification}

The effects of the DMC-to-soybean oil molar ratio (1-9 molar ratio), water content $(0-1.0 \mathrm{v} / \mathrm{v}, \%)$, enzyme ratio $(2-20 \mathrm{wt} . \%)$, and reaction temperature $\left(30-70{ }^{\circ} \mathrm{C}\right)$ and time $(0-18 \mathrm{~h})$ on the transformer insulating oil synthesis were investigated. The experiments were carried out in screw-capped vials containing $0.874 \mathrm{~g}(1 \mathrm{mmol}$ ) of soybean oil, the given amounts of DMC, Lipozyme 435 (wt. \%, based on the soybean oil weight), and water (v/v \%, based on the DMC volume), in an oil bath for the control of temperature. After the reaction was finished, products were filtered by $0.20-\mu \mathrm{m}$ hydrophobic syringe filters. The filtrate was analyzed via gas chromatography (GC) to calculate the transformer insulating oil conversion and composition. All procedures were conducted at least in triplicate.

\subsubsection{Scaling-Up of Transesterification}

To measure the transformer insulating oil properties of the FAMEs that were produced at optimum conditions, the experiment was scaled up with a 500-mL three-neck flask. This scale was designed to be approximately 100 times larger than the smaller scale mentioned above. The temperature of a reactor with a reflux condenser was controlled by a heating mantle. The reaction mixture was agitated by an impeller at $150 \mathrm{rpm}$. When the reaction was finished, the reactor was cooled to an ambient temperature. The reacted samples were filtered to remove Lipozyme 435 . The filtrate was then evaporated at $40^{\circ} \mathrm{C}$ using a rotary evaporator. Finally, the products were separated into the supernatant (transformer insulating oil) and down layer (glycerol derivatives) after evaporating the DMC.

\subsection{Analyses}

The prepared samples were analyzed with an M600D gas chromatographer (GC) (Young Lin Instrument, Anyang, Korea). The detector mode was a flame ionization detector (FID) and the column used a HP-INNOWAX (polyethylene glycol capillary column; $30 \mathrm{~m}$ length $\times 0.53 \mathrm{~mm}$ 
diameter $\times 1.00 \mu \mathrm{m}$ film). Nitrogen was used as the carrier gas. The injector and detector were maintained at $250^{\circ} \mathrm{C}$ during analysis. The oven temperature was kept at $150{ }^{\circ} \mathrm{C}$ for $5 \mathrm{~min}$, and raised to $240{ }^{\circ} \mathrm{C}$ (heating rate, $10{ }^{\circ} \mathrm{C} / \mathrm{min}$; holding time, $5 \mathrm{~min}$ ). The conversion of transformer insulating oil was determined follow the equation:

FAMEs conversion $(\%)=($ Synthesized FAMEs concentration $) /($ Theoretical FAMEs concentration $) \times 100$.

The intermediates and byproducts were confirmed by GC-MS using an Agilent 7890B GC coupled with an Agilent 5977B MS detector. The column used a HP-5 MS ((5\%-Phenyl)-methylpolysiloxane capillary column; $30 \mathrm{~m}$ length $\times 0.25 \mathrm{~mm}$ diameter $\times 0.1 \mu \mathrm{m}$ film). Helium was used as the carrier gas. The oven temperature was kept at $140{ }^{\circ} \mathrm{C}$ for $1 \mathrm{~min}$ and steadily heated to $190{ }^{\circ} \mathrm{C}$ (heating rate, $15^{\circ} \mathrm{C} / \mathrm{min}$ ), $260^{\circ} \mathrm{C}$ (heating rate, $7^{\circ} \mathrm{C} / \mathrm{min}$ ), and $300{ }^{\circ} \mathrm{C}$ (heating rate, $20^{\circ} \mathrm{C} / \mathrm{min}$; holding time, $3 \mathrm{~min}$ ). Mass spectra were investigated at an ionization energy of $70 \mathrm{eV}$.

\subsection{Determination of Transformer Insulating Oil Properties}

The measurements of insulating oil properties of the produced FAMEs were conducted by the Korea Institute of Petroleum Management based on KS (Korean Industrial Standards) and ASTM (American Society for Testing and Materials) standards. The kinematic viscosity was measured based on KS M ISO 3104 (2008), the pour point was determined as per KS M ISO 3016 (2014), the dielectric breakdown voltage was measured according to KS C IEC 60156 (2013), the water content was measured as per KS M ISO 12937 (2003), and the oxidation stability was determined based on KS C 2101 (2006). The density was determined according to ASTM D4052-15.

\section{Conclusions}

We developed a method to simultaneously produce a soybean oil-based transformer insulating oil and value-added glycerol derivatives (glycerol carbonate and glycerol dicarbonate) via DMC-based transesterification using Lipozyme 435. DMC was used as a reaction solvent to prevent the co-production of glycerol byproducts. During the transesterification reaction, the generated components, which were FAMEs, FAGCs, glycerol carbonate, and glycerol dicarbonate, were examined by GC and GC/MS analyses. At the optimum conditions, the maximum conversions of transformer insulating oil and glycerol derivatives were $92 \%$ and $72 \%$ (based on the theoretical yield), respectively. The purified transformer insulating oil obtained a dielectric breakdown voltage of $82.0 \mathrm{kV}$. The resulting transformer insulating oil can be considered as an alternative dielectric fluid due to its excellent insulation properties and low kinematic viscosity.

Acknowledgments: This research was supported by the Basic Science Research Program through the National Research Foundation of Korea (NRF) funded by the Ministry of Science and ICT(2017R1A2B4007648). This research was also supported by the C1 Gas Refinery Program through the National Research Foundation of Korea (NRF) funded by the Ministry of Science and ICT (2015M3D3A1A01064882).

Author Contributions: Keon Hee Kim designed and performed the experiments; Eun Yeol Lee coordinated the study and finalized the manuscript. All authors read and approved the manuscript.

Conflicts of Interest: The authors declare no conflicts of interest.

\section{References}

1. Gwon, M.; Baek, J.H.; Kim, M.H.; Park, D.W.; Lee, M.S. Insulation properties and evaluation of diglycerol ester synthesized by solid acid catalysts. Appl. Chem. Eng. 2014, 253, 254-261. [CrossRef]

2. Azis, N.; Jasni, J.; Ab Kadir, M.Z.A.; Mohtar, M.N. Suitability of palm based oil as dielectric insulating fluid in transformers. J. Electr. Eng. Technol. 2014, 9, 662-669. [CrossRef] 
3. Kanoh, T.; Iwabuchi, H.; Hoshida, T.Y.; Yamada, J.; Hikosaka, T.; Hatta, A.; Koide, H. Analyses of electro-chemical characteristics of palm fatty acid esters as insulating oil. In Proceedings of the 16th International Conference on Dielectric Liquids, Futuroscope-Chasseneuil, France, 30 June-3 July 2008; pp. 1-4.

4. $\quad$ Rafiq, M.; Lv, Y.Z.; Zhou, Y.; Ma, K.B.; Wang, W.; Li, C.R.; Wang, Q. Use of vegetable oils as transformer oils-A review. Renew. Sustain. Energy Rev. 2015, 52, 308-324. [CrossRef]

5. Radhika, R.V.; Iruthayarajan, M.W.; Pakianathan, P.S. Investigation of critical parameters of mixed insulating fluids. In Proceedings of the International Conference on Circuit, Power and Computing Technologies [ICCPCT], Nagercoil, India, 20-21 March 2014; pp. 357-362.

6. Li, J.; Zhang, Z.; Grzybowski, S.; Liu, Y. Characteristics of moisture diffusion in vegetable oil-paper insulation. IEEE Trans. Dielectr. Electr. Insul. 2012, 19, 1650-1656. [CrossRef]

7. Muhamad, N.A.; Phung, B.T.; Blackburn, T.R. Dissolved gas analysis (DGA) of arcing faults in biodegradable oil insulation systems. In Proceedings of the 2008 International Symposium on Electrical Insulating Materials, Mie, Japan, 7-11 September 2008; pp. 24-27. [CrossRef]

8. Cigré Working Group A2.35: Technical Brochure 436-Experiences in Service with New Insulating Liquids; Cigré: Paris, France, 2010.

9. Marx, S. Glycerol-free biodiesel production through transesterification: A review. Fuel Process. Technol. 2016, 151, 139-147. [CrossRef]

10. Leão, R.A.C.; Souza, S.P.; Nogueira, D.O.; Silva, G.M.A.; Silva, M.V.; Gutarra, M.L.E.; Miranda, L.S.M.; Castro, A.M.; Junior, I.I.; Souza, R.O.M.A. Consecutive lipase immobilization and glycerol carbonate production under continuous-flow conditions. Catal. Sci. Technol. 2016, 6, 4743-4748. [CrossRef]

11. Ilham, Z.; Saka, S. Production of biodiesel with glycerol carbonate by non-catalytic supercritical dimethyl carbonate. Lipid Technol. 2011, 23, 10-13. [CrossRef]

12. Ang, G.T.; Tan, K.T.; Lee, K.T. Recent development and economic analysis of glycerol-free processes via supercritical fluid transesterification for biodiesel production. Renew. Sustain. Energy Rev. 2014, 31, 61-70. [CrossRef]

13. Lee, O.K.; Kim, Y.H.; Na, J.G.; Oh, Y.K.; Lee, E.Y. Highly efficient extraction and lipase-catalyzed transesterification of triglycerides from Chlorella sp. KR-1 for production of biodiesel. Bioresour. Technol. 2013, 147, 240-245. [CrossRef] [PubMed]

14. Kim, K.H.; Lee, O.K.; Kim, C.H.; Seo, J.W.; Oh, B.R.; Lee, E.Y. Lipase-catalyzed in-situ biosynthesis of glycerol-free biodiesel from heterotrophic microalgae, Aurantiochytrium sp. KRS101 biomass. Bioresour. Technol. 2016, 211, 472-477. [CrossRef] [PubMed]

15. Su, E.; You, P.; Wei, D. In situ lipase-catalyzed reactive extraction of oilseeds with short-chained dialkyl carbonates for biodiesel production. Bioresour. Technol. 2009, 100, 5813-5817. [CrossRef] [PubMed]

16. Kai, T.; Mak, G.L.; Wada, S.; Nakazato, T.; Takanashi, H.; Uemura, Y. Production of biodiesel fuel from canola oil with dimethyl carbonate using an active sodium methoxide catalyst prepared by crystallization. Bioresour. Technol. 2014, 163, 360-363. [CrossRef] [PubMed]

17. Álvarez, M.G.; Chimentão, R.J.; Figueras, F.; Medina, F. Tunable basic and textural properties of hydrotalcite derived materials for transesterification of glycerol. Appl. Clay Sci. 2012, 58, 16-24. [CrossRef]

18. Lee, K.H.; Park, C.H.; Lee, E.Y. Biosynthesis of glycerol carbonate from glycerol by lipase in dimethyl carbonate as the solvent. Bioprocess Biosyst. Eng. 2010, 33, 1059-1065. [CrossRef] [PubMed]

19. Su, E.Z.; Zhang, M.J.; Zhang, J.G.; Gao, J.F.; Wei, D.Z. Lipase-catalyzed irreversible transesterification of vegetable oils for fatty acid methyl esters production with dimethyl carbonate as the acyl acceptor. Biochem. Eng. J. 2007, 36, 167-173. [CrossRef]

20. Dawodu, F.A.; Ayodele, O.O.; Xin, J.; Zhang, S. Dimethyl carbonate mediated production of biodiesel at different reaction temperatures. Renew. Energy 2014, 68, 581-587. [CrossRef]

21. Zhang, L.; Sun, S.; Xin, Z.; Sheng, B.; Liu, Q. Synthesis and component confirmation of biodiesel from palm oil and dimethyl carbonate catalyzed by immobilized-lipase in solvent-free system. Fuel 2010, 89, 3960-3965. [CrossRef]

22. Oehlenschläger, J.; Gercken, G. Synthesis and mass spectrometry of 1-acyl and 3-acyl-sn-glycerol carbonates. Lipids 1978, 13, 557-562. [CrossRef] [PubMed] 
23. Zhang, L.; Sheng, B.; Xin, Z.; Liu, Q.; Sun, S. Kinetics of transesterification of palm oil and dimethyl carbonate for biodiesel production at the catalysis of heterogeneous base catalyst. Bioresour. Technol. 2010, 101, 8144-8150. [CrossRef] [PubMed]

24. Jegannathan, K.R.; Abang, S.; Poncelet, D.; Chan, E.S.; Ravindra, P. Production of biodiesel using immobilized lipase-A critical review. Crit. Rev. Biotechnol. 2008, 28, 253-264. [CrossRef] [PubMed]

25. Seong, P.J.; Jeon, B.W.; Lee, M.; Cho, D.H.; Kim, D.K.; Jung, K.S.; Han, S.O.; Kim, Y.H.; Park, C. Enzymatic coproduction of biodiesel and glycerol carbonate from soybean oil and dimethyl carbonate. Enzyme Microb. Technol. 2011, 48, 505-509. [CrossRef] [PubMed]

26. Jo, Y.J.; Lee, O.K.; Lee, E.Y. Dimethyl carbonate-mediated lipid extraction and lipase-catalyzed in situ transesterification for simultaneous preparation of fatty acid methyl esters and glycerol carbonate from Chlorella sp. KR-1 biomass. Bioresour. Technol. 2014, 158, 105-110. [CrossRef] [PubMed]

27. Batan, L.; Quinn, J.; Willson, B.; Bradley, T. Net energy and greenhouse gas emission evaluation of biodiesel derived from microalgae. Environ. Sci. Technol. 2010, 44, 7975-7980. [CrossRef] [PubMed]

(C) 2017 by the authors. Licensee MDPI, Basel, Switzerland. This article is an open access article distributed under the terms and conditions of the Creative Commons Attribution (CC BY) license (http:// creativecommons.org/licenses/by/4.0/). 